\title{
CENTER FOR THE STUDY OF THE BATTLE OF STALINGRAD: YESTERDAY, TODAY, TOMORROW
}

\author{
Boris G. Usyk \\ Center for the Study of the Battle of Stalingrad, Volgograd, Russian Federation
}

\author{
Olga J. Redkina
}

Volgograd State University, Volgograd, Russian Federation

Irina A. Lysenko

Center for Documentation of Contemporary History of the Volgograd Region, Volgograd, Russian Federation

\begin{abstract}
The article presents some of the results of the Center for the Study of the Battle of Stalingrad for five years of work. Information is given about published collections of documents and materials, encyclopedias and reference books prepared as a result of the interaction of scientific, educational, public organizations and cultural institutions dedicated to the history of the great battle on the Volga. The paper informs about the scientific seminars held at the Center on little-studied issues of the history of the Battle of Stalingrad. The study of genuine sources and the introduction into scientific circulation of arrays of archival documents are aimed at preventing the falsification of historical events, the formation of impartial judgments and the preservation of collective memory of the war.

Key words: Center for Study of the Battle of Stalingrad, falsification of history, scientific seminars, the Astrakhan City Defense Committee, the Stalingrad Group of Forces, "white spots" in the history of the Battle of Stalingrad, preserving the collective memory of the war.
\end{abstract}

Citation. Usyk B.G., Redkina O.J., Lysenko I.A. Center for the Study of the Battle of Stalingrad: Yesterday, Today, Tomorrow. Vestnik Volgogradskogo gosudarstvennogo universiteta. Seriya 4. Istoriya. Regionovedenie. Mezhdunarodnye otnosheniya [Science Journal of Volgograd State University. History. Area Studies. International Relations], 2021, vol. 26, no. 4, pp. 246-252. (in Russian). DOI: https://doi.org/10.15688/jvolsu4.2021.4.21

\section{ЦЕНТР ПО ИЗУЧЕНИЮ СТАЛИНГРАДСКОЙ БИТВЫ: ВЧЕРА, СЕГОДНЯ, ЗАВТРА}

Борис Григорьевич Усик

Центр по изучению Сталинградской битвы, г. Волгоград, Российская Федерация

\section{Ольга Юрьевна Редькина}

Волгоградский государственный университет, г. Волгоград, Российская Федерация 


\section{Ирина Альбертовна Лысенко}

Центр документации новейшей истории Волгоградской области, г. Волгоград, Российская Федерация

Аннотация. В статье представлены некоторые итоги деятельности Центра по изучению Сталинградской битвы за пять лет работы. Приведена информация об опубликованных сборниках документов и материалов, энциклопедиях и справочниках, подготовленных в результате взаимодействия научных, образовательных, общественных организаций и учреждений культуры, посвященных истории великого сражения на Волге. Информируется о проводимых в Центре научных семинарах по малоизученным вопросам истории Сталинградской битвы.

Ключевые слова: Центр по изучению Сталинградской битвы, фальсификация истории, научные семинары, Астраханский городской комитет обороны, Сталинградская группа войск, «белые пятна» в истории Сталинградской битвы, сохранение коллективной памяти о войне.

Цитирование. Усик Б. Г., Редькина О. Ю., Лысенко И. А. Центр по изучению Сталинградской битвы: вчера, сегодня, завтра // Вестник Волгоградского государственного университета. Серия 4, История. Регионоведение. Международные отношения. - 2021. - Т. 26, № 4. - С. 246-252. - DOI: https://doi.org/10.15688/jvolsu4.2021.4.21

Город-герой Волгоград аккумулировал уникальный опыт сохранения и трансляции широкой общественности в стране и за рубежом памяти о Второй мировой войне. Важным событием стало создание в октябpe 2015 г. Центра по изучению Сталинградской битвы (далее - Центр). Центр организует взаимодействие научных, образовательных, общественных организаций, учреждений культуры, применяет как традиционные, так и инновационные формы научно-исследовательской работы. Изучение источников и введение в научный оборот массивов архивных документов направлены на предотвращение фальсификации исторических событий, формирование беспристрастных суждений и сохранение коллективной памяти о войне.

Цель работы Центра - научное исследование истории Сталинградской битвы и ее влияния на ход Великой Отечественной войны, отображение результатов исследований в печатных и иных изданиях [13]. Идею создания небольшой группы профессиональных историков, которая занимается этим на постоянной основе, поддержал Президент РФ В.В. Путин на мероприятиях, посвященных 70-летию Победы в Сталинградской битве.

Президент России неоднократно отмечал важность работы по сохранению исторической памяти, противодействия ее искажению. Так, на заседании Российского организационного комитета «Победа» 21 мая 2021 г. он обратил внимание на то, что «в числе поправок в обновленную Конституцию, получив- ших самую большую народную поддержку, вошло положение, посвященное именно сохранению памяти защитников Отечества, сбережению исторической правды» [6].

Об этом В.В. Путин говорил и ранее. «Продуманная и честная патриотическая повестка должна укреплять в новых поколениях базовые ценности, которые отражают традиции, национальную идентичность, весь исторический путь страны. И здесь особая роль принадлежит Великой Отечественной войне, неотделимой от истории каждой российской семьи» [7].

Президент призывает защищать историческую память и имена героев. «Наш ответ на ложь - это правда. Мы продолжим рассказывать о событиях, фактах Великой Отечественной войны, раскрывать и публиковать архивные материалы во всей их полноте» [7]. Данными словами можно выразить основные направления развития Центра.

Инициатива создания Центра принадлежала М.М. Загорулько, доктору экономических наук, профессору, заслуженному деятелю науки Российской Федерации, почетному гражданину Волгоградской области и городагероя Волгограда, участнику Великой Отечественной войны.

Центр был создан 12 октября 2015 г. постановлением Губернатора Волгоградской области А.И. Бочарова. В настоящее время в его составе 10 сотрудников, в большинстве своем имеющих ученые степени и звания. Они продолжают, прежде всего, работу над энциклопедией: «Сталинградская битва: Июль 
1942 - февраль 1943 г.». В создании крупного научного труда приняли участие более 500 авторов из 71 региона РФ и 7 стран СНГ. Энциклопедия неоднократно переиздавалась в дополненных вариантах. В 2020 г. вышло в свет 8-е издание, в которое включены новые статьи, добавлен ряд таблиц. С учетом вновь выявленных сведений переработаны приложения «Командный состав Волжской военной флотилии в период Сталинградской битвы»; «Герои Советского Союза и Герои РФ, удостоенные звания за подвиги в Сталинградской битве», «Приказ Наркома обороны СССР № 312 от 22 сентября 1941 г. о введении новых норм продовольственного снабжения Красной армии» [9].

С переведенной на английский язык энциклопедией «Сталинградская битва» смогли познакомиться ветераны Второй мировой войны из США, Франции, Великобритании, исследователи и сотрудники музеев Германии, Болгарии, Финляндии.

Деятельность Центра по предотвращению фальсификации истории осуществляется путем ведения работы с архивными документами, выявления исторических фактов, их перепроверки в доступных источниках. В дальнейшем проводится научная обработка материалов, подготовка к публикации, и в свет выходят энциклопедические и информационностатистические справочники, сборники документов по вопросам истории и экономики Сталинградской области военного периода. Большинство из них были изданы при финансовой поддержке Российского гуманитарного научного фонда, Российского фонда фундаментальных исследований, Администрации Волгоградской области и Администрации г. Волгограда.

Первым вышел в свет сборник документов «Восстановление экономики Сталинградской области (репарационные поставки) 1945 1947 гг.» (проект РГНФ № 15-01-00425) [4]. Сборник подготовлен в сотрудничестве и с использованием ранее неопубликованных документов ГКУ ВО «Государственный архив Волгоградской области», характеризует основные этапы поставок и процесс организации использования репарационного оборудования.

В рамках проекта «Сталинградская область в годы Великой Отечественной войны (1941-1945): власть, экономика, общество», поддержанном РФФИ, были изданы несколько сборников документов. В сотрудничестве с ГКУ АО «Государственный архив Астраханской области», ГКУ АО «Государственный архив современной документации Астраханской области» и государственными архивами Волгоградской области опубликован сборник «Астраханский городской комитет обороны», информация о деятельности которого ранее была недостаточно освещена [1].

При содействии сотрудников территориального органа Федеральной службы государственной статистики по Волгоградской области, Государственного архива Волгоградской области, Центра документации новейшей истории Волгоградской области был подготовлен двухтомный информационно-статистический справочник «Сталинградская область 1939-1943 гг.». В нем дана комплексная характеристика административно-территориального деления, демографической ситуации, социальной сферы. Приведена статистическая информация о промышленности и сельском хозяйстве $[11 ; 12]$.

В сборник документов и материалов «Сталинградская группа войск. 1943-1944», посвященный восстановлению и налаживанию мирной жизни города и области при поддержке воинских формирований - участников Сталинградского сражения, включены документы Центрального архива министерства обороны и государственных архивов Волгоградской области [10].

В содружестве с ФГУПК «Государственный историко-мемориальный музей-заповедник Сталинградская битва» вышел в свет энциклопедический справочник «ВолжскоКаспийский бассейн в 1942-1943 гг.», который характеризует работу тружеников портов и пристаней, рабочих и инженерно-технических работников судоремонтно-судостроительных заводов и верфей, нефтебаз [3]. В 2020 г. подготовлено 2-е издание справочника, в него включены 82 новые статьи и 39 ранее неопубликованных документов, отражающих работу транспортного флота, тружеников портов и военных моряков Каспийского моря в 19411943 годах.

Энциклопедия «Баррикадный район Сталинграда. Завод “Баррикады”. 1941-1945» [2] предваряет начало большой работы по фор- 
мированию энциклопедических справочников, посвященных роли и значению деятельности районов Сталинграда и области в период Великой Отечественной войны. В нее включены статьи, позволяющие составить представление о работе завода «Баррикады», вкладе жителей района в Сталинградскую победу, об эвакуации заводчан в тыл и их труде на различных предприятиях Народного комиссариата вооружения СССР, о восстановлении района и завода после победы.

Подготовлен к публикации сборник документов и материалов «Потребительская и промысловая кооперация Сталинградской области (1942-1943 гг.)», в котором рассматривается деятельность двух крупных хозяйственных систем в период войны, показываются особенности их многоотраслевой деятельности, значение для жизни населения и оказания помощи армии и флоту.

Апробация результатов исследований Центра проходит на научных конференциях международного, национального, регионального уровней.

С 2015 по 2021 г. в Центре по изучению Сталинградской битвы ежемесячно проводятся научные семинары, преимущественно в форме круглых столов, в том числе в он-лайн-формате. Участниками являются: д.э.Н., проф. М.М. Гузев, д. искусств., проф. О.И. Луконина, д.и.н., проф. С.Г. Сидоров, д.и.н., доц. Е.В. Булюлина, к.и.н., доц. О.А. Гоманенко, к.и.н., доц. Е.В. Огаркова, к.и.н. С.Ю. Пищулина, к.и.н. И.А. Рябец и др. В работе научных семинаров принимают участие сотрудники государственных архивов Волгоградской области, областной и городской библиотек, музеев, аспиранты и студенты. На заседаниях выступают представители общественных организаций: городской совет ветеранов (председатель - А.Д. Струков), Волгоградская региональная общественно-патриотическая организация «Клуб “Сталинград”» (представитель - к.пед.н., доц. М.Е. Чулкова), международный благотворительный фонд «Сталинградская битва» (представитель А.В. Джегло), общественная организация «За верность Отечеству» (представитель Е.А. Черенкова). Свои наработки представляют исследователи-краеведы В.Е. Алабушев, А.К. Медведев, А.А. Смирнов и др.
В рамках научных семинаров рассматриваются недостаточно изученные вопросы истории Сталинградской битвы, так называемые «белые пятна» [5]. Продолжая традиции, заложенные научной школой М.M. Загорулько в НИИ ПЭИР Волгоградского государственного университета [4, с. 190-197], большое внимание уделяется экономическим проблемам периода Великой Отечественной войны.

Всего состоялось свыше 50 семинаров. Тематика, предлагавшаяся к обсуждению в 2019-2021 гг., чрезвычайно широка: «Вооружение судов Волжского речного флота в период Сталинградской битвы», «Командный состав РККА в Сталинградской битве», «Культурно-историческое наследие Сталинградской битвы», «Медицинское обеспечение Красной армии в период Сталинградской битвы», «Современная библиография о Сталинградской битве», «Минирование противником г. Сталинграда и области радиоуправляемыми минами», «Сталинградская область накануне и в начальный период Великой Отечественной войны», «Россошинское военно-мемориальное кладбище: прошлое и настоящее. Уроки исторической памяти», «Сарепта в период Великой Отечественной войны», «Промысловая и потребительская кооперация Сталинградской области (1942-1943 гг.)», «Захоронения советских воинов, погибших в период Сталинградской битвы на территории Среднеахтубинского района», «Сохранение памяти о Сталинградской битве в печатных источниках на территории Волгоградской области», «Сталинградские конструкторы и разработчики оружия в период Великой Отечественной войны», «Формы увековечения памяти погибших при защите Отечества (на примере Красноармейского района города Волгограда)», «Сталинградский областной суд в период Великой Отечественной войны», «Астраханский промышленный узел в 1941-1943 гг.», «Медики Сталинграда в период Великой Отечественной войны», «Отражение Сталинградской битвы в кинохрониках и художественных фильмах», «Организация сельскохозяйственных работ на территории области в период Сталинградской битвы», «Противоэпидемические мероприятия в Астраханском округе в 19411943 гг.» и мн. др. [9]. Обсуждение малоизученных проблем истории Сталинградской битвы 
позволяет определить новые направления научного поиска, привлечь к исследовательской работе широкие круги общественности, заинтересованные в сохранении памяти о Сталинградской битве [8].

Информация о различных направлениях деятельности Центра размещена на официальном сайте [13]: научные публикации, международное и межрегиональное сотрудничество, Вестник Центра по изучению Сталинградской битвы (выходит с 2016 г.) и др. В частности, Центр приглашает к сотрудничеству исследователей в работе над проектами: «Награжденные медалью “За оборону Сталинграда"», «Ратное поле России», «Советские военнопленные в Сталинградской битве», «Камышинский городской комитет обороны», «Органы государственной власти Сталинградской области в 1941-1945 гг.», «Торговля и снабжение в период Сталинградской битвы».

Центр приступил к формированию библиотеки, в которой аккумулируется мемуарная литература, фотодокументы, материалы конференций, фотоальбомы, газеты и другие источники, связанные со Сталинградской битвой.

Таким образом, за пять лет работы Центр стал единственным специализированным в Волгоградской области научным учреждением, осуществляющим целенаправленную деятельность по комплексному исследованию истории Сталинградской битвы, ведущим работу по предотвращению фальсификации исторических событий периода Второй мировой войны, координирующим разноплановую исследовательскую, публикаторскую и просветительскую деятельность научных и общественных кругов. Приближающийся юбилей 80-летия победы под Сталинградом придает новый импульс в реализации проектов Центра, определенных Администрацией Волгоградской области.

\section{СПИСОК ЛИТЕРАТУРЫ}

1. Астраханский городской Комитет обороны в годы Великой Отечественной войны : документы и материалы / под ред. М. М. Загорулько ; сост.: В. В. Булатов [и др.]. - Волгоград : Издатель, 2017. $280 \mathrm{c}$.

2. Баррикадный район Сталинграда. Завод «Баррикады». 1941-1945 : энциклопедия / авт.- сост.
В. Е. Алабушев. - Волгоград : Издатель, 2020. $296 \mathrm{c}$.

3. Волжско-Каспийский бассейн в $1942-$ 1943 годах: обеспечение коренного перелома в войне. Т. 1. Боевые навигации на Нижней Волге и Северном Каспии (1942-1943) : энцикл. справ. / под ред. М. М. Загорулько ; авт.-сост. В. В. Булатов [и др.]. - Волгоград : Издатель, 2019. - 256 с.

4. Восстановление экономики Сталинградской области. Репарационные поставки. 1945-1947 : документы и материалы / под ред. М. М. Загорулько. - Волгоград : Издатель, 2016. - 240 с.

5. Загорулько, М. М. Научные семинары Центра по изучению Сталинградской битвы / М. М. Загорулько, И. А. Лысенко // Вестник Волгоградского государственного университета. Серия 4, История. Регионоведение. Международные отношения. 2017. - Т. 22, № 4. - С. 178-185.

6. Заседание Российского организационного комитета «Победа». Под председательством Владимира Путина в режиме видеоконференции состоялось 43-е заседание Российского организационного комитета «Победа» 20 мая 2021 года. - Электрон. текстовые дан. - Режим доступа: http:// kremlin.ru/events/president/news/65618 (дата обращения: 22.05.2021). - Загл. с экрана.

7. Латухина, К. Память и гордость. Владимир Путин обещал защитить правду о войне / К. Латухина // Российская газета. - 2019. - № 28 (8039). Электрон. текстовые дан. - Режим доступа: https:// rg.ru/2019/12/12/vladimir-putin-obeshchal-zashchititpravdu-o-vojne.html (дата обращения: 23.05.2021). Загл. с экрана.

8. Редькина, О. Ю. Научная школа профессора М. М. Загорулько / О. Ю. Редькина, В. В. Булатов // Вестник Волгоградского государственного университета. Серия 4, История. Регионоведение. Международные отношения. - 2013. - Т. 18, №2. - С. 190-197.

9. Сталинградская битва. Июль 1942 - февраль 1943 : энциклопедия / под ред. М. М. Загорулько ; Администрация Волгоградской области, Центр по изучению Сталинградской битвы. - 8-е изд. доп. Волгоград : Издатель, 2020. - 848 с., ил.

10. Сталинградская группа войск. 1943-1944 гг. : документы и материалы / под ред. О. А. Гоманенко, М. М. Загорулько. - М. : Полит. энцикл., 2019. 769 с. : ил.

11. Сталинградская область (1939-1943). Цифры и факты : информ.-стат. справ. В 2 т. Т. 1. Территория. Население. Власть. Социальная сфера / под ред. М. М. Загорулько. - Волгоград : Издатель, 2016. $423 \mathrm{c}$.

12. Сталинградская область (1939-1943). Цифры и факты : информ.-стат. справ. В 2 т. Т. 2. Промышленность. Сельское хозяйство. Водный транспорт 
/ под ред. М. М. Загорулько. - Волгоград : Издатель, 2017. -352 c.

13. Центр по изучению Сталинградской битвы. - Электрон. текстовые дан. - Режим доступа: http://www.centre-stalingrad.volglib.ru (дата обращения: 17.03.2021). - Загл. с экрана.

\section{REFERENCES}

1. Zagorulko M.M., Bulatov V.V. et al., eds. Astrahanskij gorodskoj Komitet oborony v gody Velikoj Otechestvennoj vojny: dokumenty i materialy [Astrakhan City Defense Committee During the Great Patriotic War. Documents and Materials]. Volgograd, Izdatel Publ., 2017. 280 p.

2. Alabushev V.E., ed. Barrikadnyj rajon Stalingrada. Zavod «Barrikady». 1941-1945: enciklopediya [Barricade District of Stalingrad. The Barrikady Plant. 1941-1945. Encyclopedia]. Volgograd, Izdatel Publ., 2020. 296 p.

3. Zagorulko M.M., Bulatov V.V. et al., eds. Volzhsko-Kaspijskij bassejn v 1942-1943 godah: obespechenie korennogo pereloma v vojne. T. 1. Boevye navigacii na Nizhnej Volge i Severnom Kaspii (19421943): encikl. sprav. [Volga-Caspian Basin in 1942-1943: Providing a Fundamental Turning Point in the War. T. 1. Combat Navigation on the Lower Volga and the Northern Caspian Sea (1942-1943). Encyclopedic Reference]. Volgograd, Izdatel Publ., 2019. 256 p.

4. Zagorulko M.M., ed. Vosstanovlenie ekonomiki Stalingradskoj oblasti. Reparacionnye postavki. 1945-1947: dokumenty i materialy [Economic Recovery of the Stalingrad Region. Reparation Deliveries. 1945-1947. Documents and Materials]. Volgograd, Izdatel Publ., 2016. 240 p.

5. Zagorulko M.M. Lysenko I.A. Nauchnye seminary Centra po izucheniyu Stalingradskoj bitvy [Scientific Seminars of the Center for the Study of the Battle of Stalingrad]. Vestnik Volgogradskogo gosudarstvennogo universiteta. Seriya 4, Istoriya. Regionovedenie. Mezhdunarodnye otnosheniya [Science Journal of Volgograd State University. History. Area Studies. International Relations], 2017, vol. 22, no. 4, pp. 178-185.

6. Zasedanie Rossijskogo organizacionnogo komiteta «Pobeda». Pod predsedatel'stvom Vladimira Putina $v$ rezhime videokonferencii sostoyalos' 43-e zasedanie Rossijskogo organizacionnogo komiteta
«Pobeda» 20 maya 2021 goda [Meeting of the Russian Organizing Committee "Pobeda" (Victory). Under the Chairmanship of Vladimir Putin, the $43^{\text {rd }}$ Meeting of the Russian Organizing Committee "Pobeda" (Victory) Was Held on May 20, 2021]. URL: http://kremlin.ru/events/ president/news/656188 (accessed 22 May 2021).

7. Latukhina K. Pamyat' i gordost'. Vladimir Putin obeshchal zashchitit' pravdu o vojne [Memory and Pride. Vladimir Putin Promised to Protect the Truth About the War]. Rossiyskaya gazeta, 2019, no. 28 (8039). URL: https://rg.ru/2019/12/12/vladimir-putinobeshchal-zashchitit-pravdu-o-vojne.html (accessed 23 May 2021).

8. Redkina O.Yu., Bulatov V.V. Nauchnaya shkola professora M.M. Zagorulko [Scientific School of Professor M.M. Zagorulko]. Vestnik Volgogradskogo gosudarstvennogo universiteta. Seriya 4, Istoriya. Regionovedenie. Mezhdunarodnye otnosheniya [Science Journal of Volgograd State University. History. Area Studies. International Relations], 2013, vol. 18, no. 2, pp. 190-197.

9. Zagorulko M.M., ed. Stalingradskaya bitva. Iyul' 1942 - fevral' 1943 : enciklopediya [The Battle of Stalingrad. July 1942 - February 1943. Encyclopedia]. Volgograd, Izdatel Publ., 2020. 848 p., il.

10. Gomanenko O.A., Zagorulko M.M., eds. Stalingradskaya gruppa vojsk. 1943-1944 gg.: dokumenty $i$ materialy [Stalingrad Group of Forces. 1943-1944. Documents and Materials]. Moscow, Politicheskaya entsiklopediya Publ., 2019. 769 p., il.

11. Zagorulko M.M., ed. Stalingradskaya oblast' (1939-1943). Cifry i fakty: inform.-stat. sprav. V $2 t$. T. 1. Territoriya. Naselenie. Vlast'. Social'naya sfera [Stalingrad Region (1939-1943). Figures and Facts. Statistical Reference Book. In 2 Vols. Vol. 1. Territory. Population. Power. Social Sphere]. Volgograd, Izdatel Publ., 2016. 423 p.

12. Zagorulko M.M., ed. Stalingradskaya oblast' (1939-1943). Cifry i fakty: inform.-stat. sprav. V 2 t. T. 2. Promyshlennost'. Sel'skoe hozyajstvo. Vodnyj transport [Stalingrad Region (1939-1943). Figures and Facts. Statistical Reference Book. In 2 Vols. V. 2. Industry. Agriculture. Water Transport]. Volgograd, Izdatel Publ., 2017. 352 p.

13. Centr po izucheniyu Stalingradskoj bitvy [Center for the Study of the Battle of Stalingrad]. URL: http://www.centre-stalingrad.volglib.ru (accessed 17 March 2021). 


\section{Information About the Authors}

Boris G. Usyk, Candidate of Sciences (History), Academic Adviser, Center for the Study of the Battle of Stalingrad, Chujkova St, 43, 400005 Volgograd, Russian Federation, Centre-Stalingrad@mail.ru, https://orcid.org/0000-0001-7092-205X

Olga J. Redkina, Doctor of Sciences (History), Professor, Department of International Relations, Political Science and Area Studies, Volgograd State University, Prosp. Universitetsky, 100, 400062 Volgograd, Russian Federation, redkina@volsu.ru, https://orcid.org/0000-0002-8978-9575

Irina A. Lysenko, Candidate of Sciences (Economics), Head of Research Department, Center for Documentation of Contemporary History of the Volgograd Region, Dymchenko St, 16, 400005 Volgograd, Russian Federation, Lysenkoia777@rambler.ru, https://orcid.org/0000-0003-2241-8670

\section{Информация об авторах}

Борис Григорьевич Усик, кандидат исторических наук, научный руководитель Центра по изучению Сталинградской битвы, Центр по изучению Сталинградской битвы, ул. Чуйкова, 43, 400005 г. Волгоград, Российская Федерация, Centre-Stalingrad@mail.ru, https://orcid.org/0000-0001-7092-205X

Ольга Юрьевна Редькина, доктор исторических наук, профессор кафедры международных отношений, политологии и регионоведения, Волгоградский государственный университет, просп. Университетский, 100, 400062 г. Волгоград, Российская Федерация, redkina@volsu.ru, https://orcid.org/0000-0002-8978-9575

Ирина Альбертовна Лысенко, кандидат экономических наук, начальник отдела научно-исследовательской работы, Центр документации новейшей истории Волгоградской области, ул. Дымченко, 16, 400005 г. Волгоград, Российская Федерация, Lysenkoia777@rambler.ru, https://orcid.org/0000-0003-2241-8670 